\title{
URANIUM STUDIES IN THE TIMS BRANCH AND STEED POND SYSTEM (U)
}

by

D. W. Hayes

Westinghouse Savannah River Company

Savannah River Site

Aiken, South Carolina 29808

Technical deliverable being deposited with OSTI.

The information contained in this report was prepared in connection with work done under Contract No. DE-AC09-76SR00001 with the U.S. Department of Energy. By acceptance of this report, the publisher and/or recipient acknowledges the U.S. Government's right to retain a nonexclusive, royalty-free license in and to any copyright covering this report, along with the right to reproduce and to authorize others to reproduce all or part of the copyrighted report. 
TECHNICAL DIVISION

SAVANNAH RIVER LABORATORY

$+\ldots$

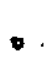

CC: W. M. Olliff, SRP

J. D. Clayton

L. P. Fernandez

H. C. Drannon

C. F. Muska

M. D. S. Turcotte

J. S. Roberts

M. B. Hughes

M. W. Lewis

C. A. Palmiotto

D. I. Ross

C. C. Zeigler

T. V. Crawford, SRL

A. L. Boni

J. C. Corey

J. B. Pickett

November 1,1984

\section{MEMORANDUM}

TO: R. W. BENJAMIN

FROM: D. W. HAYES Nut

\section{ORANIOM STODIES IN TRE TIMS BRANCE AND STBED POND SYSTEY}

\section{SUMMARY}

During the weekend of September $2-3,1984$, a part of the wooden spillway for steed Pond gave way and the pond slowly drained. Consideration is being given to leaving steed pond dry. steed Pond has accumulated some of the uranium discharged from 300 Area operations and past surveys have shown that the uranium concentration in the sediments ranges between 20 and $531 \mathrm{pci} / \mathrm{gm}$. 
The recently completed aerial survey of the exposed area of Steed Pond showed that the uranium was widely spread in the sediments of steed Pond. Until ground cover is established over the exposed pond sediments, they will be subject to erosion. As much as 90 tons of sediment could be exoded from the exposed sediments in Steed Pond the first year, but the erosion could be reduced to 5 - 15 tons by establishing a ground cover such as rye grass. Only about 408 of the eroded sediment would be delivered to Upper Three Runs creek, because most of the eroded sediment deposited before it reaches Upper Three Runs Creek. Less than 20 mCi of uranium would be transported downstream the first year from erosion of Steed Pond sediments, and this could be reduced to 2-5 mCi/year if ground cover is established.

The preliminary results from these calculations were reported at a Steed Pond review on September 20, 1984.

\section{INTRODUCTION}

The 300 area operations have discharged about 24 curies of alpha activity (uranium) to Tims Branch since 1954. Tims Branch flows through steed Pond, over a wooden spillway and then downstream until it empties into Upper Three Runs creek at Road c. Based on monitoring of Upper Three Runs Creek, nearly all of the alpha activity discharged from 300 Area operations was deposited in the Tims Branch and Steed Pond stream system. During the 
weekend of September 2-3, 1984, a part of the wooden spillway gave way and the pond slowly drained. The sediments in steed Pond containing uranium from 300 Area releases are now exposed and subject to erosion. Earlier analyses of a few surface sediment samples from the pond indicate that the uranium concentration ranges from 20 to $531 \mathrm{pCi} / \mathrm{gm}$ in the sediments. Since some consideration is being given to leaving the spillway open and the pond drained, an analysis of the amount of uranium that might be transported from the exposed sediment in steed Pond and the conaitions that resulted in uranium originally being deposited in the Tims Branch and steed Pond stream system was studied.

\section{DISCUSSION}

\section{Alpha Activity Source}

About 24 curies of alpha activity have been discharged to the Tims Branch system from 300 Area fuel target fabrication operations (Figure 1). From the early 1950's until the mid $1960^{\prime} \mathrm{s}$, most of the alpha activity discharged was natural uranium $(0.728 \mathrm{U}-235)$ along with a small amount of enriched uranium $(0.898$ U-235). The alpha activity discharged since the mid 1960's is due to depleted uranium (0.28 U-235). A small amount of alpha activity from Th-232 may have been released in 1967 and 1968 . 
The source of this discharged alpha activity is waste from cleaning and recovery operations in the 300 Area. In the process of making the fuel or target elements, uranium slugs are cleaned in step operations with perchloroethylene, nitric and phosphoric acids. The cleaning removes alpha activity from the surfaces of the slugs used to fabricate fuel or target elements. The used chemicals from this cleaning operation are treated and the waste water containing traces of the residual alpha activity is discharged. Some alpha activity in the waste water was also released from the process used to recover uranium from fuel and target elements that failed specifications or tests. The waste water from all these sources entered a Tims Branch tributary near the 700 Area waste water treatment plant on Road D (Figure 2). An accounting of the gross alpha activity released at the discharge point and the alpha activity in transport in Upper Three Runs Creek below the confluence with Tims Branch (at Road C), shows that most of the alpha activity discharged is still in the Tims Branch system. About 8 curies of the total alpha activity was measured in transport in Upper Three Runs as compared to 24 curies of alpha activity discharged to Tims Branch from 300 Area operations. Even during years of peak alpha activity discharges from the 300 Area, the alpha activity in transport in Upper Three Runs Creek remained nearly constant (compare figure 3). These results show that most of the alpha activity is still in the Tims 
Branch system. The actual 300 area alpha activity contributions to Upper Three Runs Creek cannot be accurately evaluated because the concentrations are very low due to dilution and near background alpha activity levels. However, source of uranium in transport in Upper Three Runs Creek could be determined by measuring the uranium isotopic ratio.

\section{Alpha Activitîy Deposition}

The recently completed aerial radiological survey of the rims Branch system by EG\&G show that the locations of the major depositional areas for uranium are near the entrance of 300 Area effluents into Tims Branch and steed Pond (Figure 2). The area between Steeds Pond and Upper Three Runs did not show the presence of U-238. The U-238 was identified by the presence of Pa-234, a natural chain daughter product of $\mathrm{U}-238$.

The conditions for deposition of uranium in Tims Branch is influenced by the stream morphology. The discharges from the 300 Area enter a tributary of Tims Branch adjacent to Road $D$ and the railroad track (figure 2) and flow down a rather steep siope which intersects with rims Branch (Figure 4). Over the years considerable erosion has occurred in this tributary as it adusted to accommodate the increased flow from the 300 Area and to increased peak storm flow due to large buildings and paved areas in the headwaters of the tributary. The erosion in the tributary prevented the deposition of appreciable quantities of uranium in the tributary. At the bottom of this slope most of the eroded 
sediment was deposited in the floodplain of Tims Branch near the intersection. The abrupt change in slope at this point 138 to 0.48 ) reduced the capacity of the water to carry the sediment so this was where most of the sediment was deposited.

The water then flows a low slope $(0.48)$ distance of about 5800 feet until it enters Steed Pond. Steed Pond acts as a settling basin and has a residence time for Tims Branch water flow of about 3 days ( 11 acres * 43560 feet $2 /$ acre * 4 feet $/ 5$ cfs). This residence time is sufficient for the settling of flow-borne alpha activity as evidenced by the presence of $0-238$ in the sediments of Steed Pond. An accumulation of sediment of about 3 feet in the vicinity of the Steed Pond spillway shows the result of sediment deposition.

Steed Pond originally had an area of about 14 acres, and an area of about 11 acres when the spillway gave way in September 1984. In the early 1960's the spillway was removed and the pond drained. Based on aerial photos, the pond still had a few acres of water in 1966 indicating that the spillway was only partially removed. In the early 1970's the spillway was repaired and the pond returned to a surface area of about 11 acres, about 3 acres less than the original 14 acres. Because the spillway has never been completely removed, the pond has always functioned as a sediment trap with varying efficiencies based on the amount of water in the pond. 
After the water leaves Steed Pond, it travels about 13,700 feet at about the same slope $(0.48)$ until it enters Upper Three Runs. Since the slope gradient below Steed pond is the same as above the pond, it is an extension of the depositional conditions that exist in the area above steed pond.

The chemistry of the waste water effluents from the 300 Area and the presence of eroded sediments have probably enhanced the deposition of uranium. The waste water effluent contained phosphates, and phosphates form insoluble compounds with uranium which could be deposited. The eroded sediments provide sorption surfaces for the discharged uranium ( $k d$ about 50 ) and in addition phosphates could sorb to sediment surfaces and form an enhanced sorbant for uranium from solution to the sediments.

Toxicity

The chemical toxicity of uranium may be more important than the radiotoxicity. The ICRP in establishing radiologic concentration guides, recognized that the chemical toxicity of the longer lived nuclides $(U-235$ and $U-238)$ was the limiting criterion (ICRP Publication 2, 1960). In the National Interim Primary Drinking Water Standards no maximum contaminant levels have been established for uranium. The DOE alpha activity guideline is 30 $\mathrm{pCi} / \mathrm{L}$. 
Proposed effluent limitations for the 300 Area operations were made by DHEC. In a letter to DOE (January 31, 1984) effluent limitations for uranium of $0.2 \mathrm{mg} / \mathrm{L}$ monthly average and $0.4 \mathrm{mg} / \mathrm{L}$ instantaneous maximum were proposed for the M-Area treatment plant discharges (see Appendix $A$ ). These proposed effluent guidelines were estimated from a toxicity study done on fathead minnows and water flow balances in the area that would result in a stream concentration of $0.015 \mathrm{mg} / \mathrm{L}$.

No stream water concentration guidelines exist for the movement of established floodplain uranium downstream.

\section{Transport of 0 From Steeds Pond}

The exposed sediments of Steed pond are subject to the processes of erosion and transport down Tims Branch and into Upper Three Runs creek. An estimate of the amount of sediment that could be eroded from the exposed sediments was obtained using the Universal Soil Loss Equation (USLE, Appendix).

The USLE equation includes the factors that are important in estimating the amount of erosion (soil movement to the base of a slope), and the US Department of Agriculture has developed sets of specific and regional factors for use in the USLE equation. Approximately 90 tons of sediment may be eroded in steed Pond (10 acres). Not all of this sediment will reach Upper Three Runs creek. During the erosion stream delivery process, most of this 
soil will be deposited near the bottom of the slope and a small amount will be lost in stream transport. A correction for this reduced sediment yield downstream is made by using factors called delivery ratios. Delivery ratios are about 0.4 for small watershed streams in the sandhilis of South Carolina. Therefore, about 36 tons/year $(90$ tons $* 0.4)$ of sediment may be delivered to Upper Three Runs Creek the first year.

The amount of alpha activity that may be transported to upper Three Runs can be estimated from the erosion yield and uranium concentration in steed Pond sediments. A survey of steed pond sediments was made in 1966, from these 6 samples most of the uranium was found in the surface sediments and the concentration ranged from 20 to $531 \mathrm{pCi} / \mathrm{gm}$. Using a concentration of $531 \mathrm{pCi} / \mathrm{gm}$ a maximum of about $17 \mathrm{mCi}$ per year would be transported to upper Three Runs. This $17 \mathrm{mCi}$ would convert to an average annual uranium concentration in Tims Branch water of about $3.8 \mathrm{pCi} / \mathrm{L}$ at a flow of 5 cfs. The alpha activity contribution from this erosion would result in an increase of alpha activity in Upper Three Runs Creek of about $0.07 \mathrm{pCi} / \mathrm{L}$, which is about 108 of the alpha activity concentration present in Upper Three Runs Creek 10.8 $\mathrm{pCi} / \mathrm{L})$.

The alpha activity concentration can be translated to concentration of uranium by using the specific activity for natural uranium of $3000 \mathrm{~kg} / \mathrm{Ci}(333 \mathrm{pCi} / \mathrm{mg})$. Therefore, the 
average annual uranium concentration in Tims Branch water below Steeds pond would be about $0.011 \mathrm{mg} / \mathrm{L}$.

The amount of erosion of the exposed sediments in steed Pond can be greatly reduced if ground cover is established. In the fertile exposed sediments of steed Pond, revegetation will be especially rapid next spring. Even now some grass can be seen growing in the exposed sediments (October 25, 1984). If ground cover (rye grass) is established now and there is natural revegetation next spring, the overall reduction in erosion yield during the first year would be a factor of 10 to 15 . This reduction occurs because the cropping management factor is reduced from 0.5 to 0.03-0.05. The estimates of sediment transport, alpha activity, and uranium concentration would be reduced by the same factors. The alpha activity concentration in Tims Branch below steed pond would be reduced to $0.38 \mathrm{pCi} / \mathrm{L}$.

The calculations made include only hill-slope erosion processes. Additional sediment may be transported to Upper Three Runs Creek, if the entire spillway is removed. Over the years considerable sediment has accumulated in the pond and if the spillway were entirely removed, the stream would cut through these accumulated sediments. The sediments would move downstream and into Upper Three Runs Creek. No estimate has been made on the quantity of sediment that might be moved by this process, because no data are available on the accumulation of sediment in the pond. 
Some aerial stereo photo pairs are currently being processed to estimate the amount of sediment that might have been accumulated in Steeds Pond.

\section{PROGRAM}

A program has been started to assess the yield of sediment and uranium from the erosion of the exposed sediments in steed Pond and the environmental parameters that most strongly affect the erosion and transport of these pollutants. The program elements are:

1. The amount of sediment and uranium from the erosion of sediments in steed Pond will be determined from the analysis of water samples taken by automatic water samplers located below the steed Pond Dam.

2. The amount of the sediment and uranium that reach upper Three Runs Creek will be determined from water samples taken at the mouth of Tims Branch.

3. A recording rain gauge has been installed at Steeds Pond to determine the effect of the intensity, amount, and duration of rainfali on the sediment yield from erosion of sediments in Steed Pond.

4. To evaluate Steed Pond as a settling basin during heavy rains, a water level recorder will be installed on the pond side of the dam. 
5. The measurements from items 1 and 2 above will be interpreted in view of the results from 3 and 4. 


\section{APPENDIX}

$A=\operatorname{RKLSCP}$

$A=$ Soil loss rate in tons/acre-year.

$R$ = The rainfall intensity factor, which relates both the amount of rain and its intensity and is about 260 for this area.

$K=$ The soil erodability index is dependent upon the type of soil and the logical candidate soil would be of the Bayboro type, a silty clay loam soil. The soil erodability index for this soil is 0.17 .

LS = The hillslope length and hillslope gradient factors are combined. A slope of 38 was estimated by taking the approximate distance from the edge of the pond to the centerline ( 300 feet) and dividing it by the change in elevation from the edge to the center (about 8 feet). A factor of 0.4 was obtained from slope-slope length tables (Table 1)

$P=$ The erosion control factor includes practices such as contouring to reduce erosion. Because no erosion control methods are to be employed for steeds Pond, this factor is set at 1 (coefficients are 1 or less).

$c=$ The cropping management factor includes the effect of vegetative cover. Without any vegetative cover over the exposed sediments, this factor is about 0.5 . 


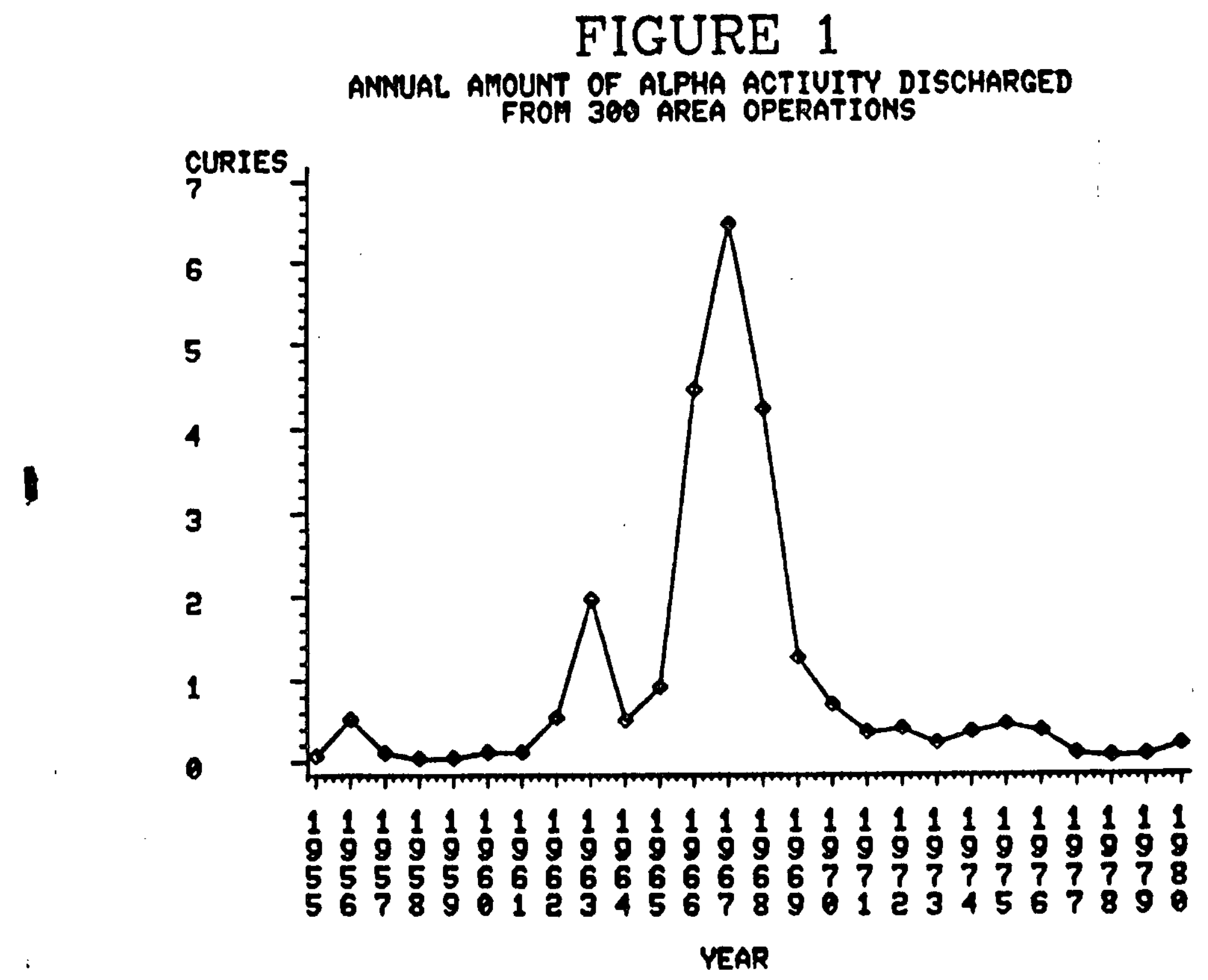


Figure 2. Map of Steed Pond and Tims Branch System

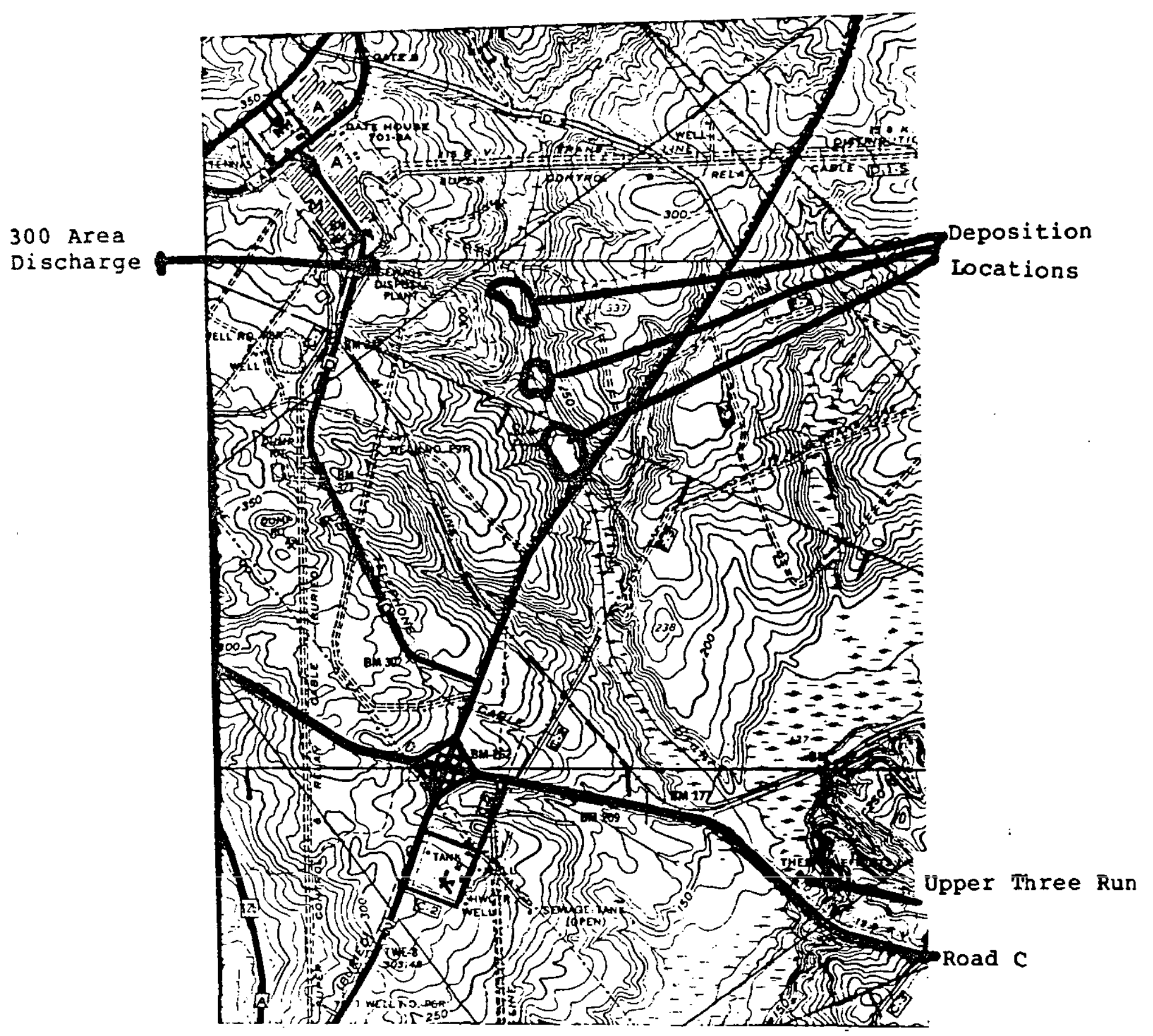




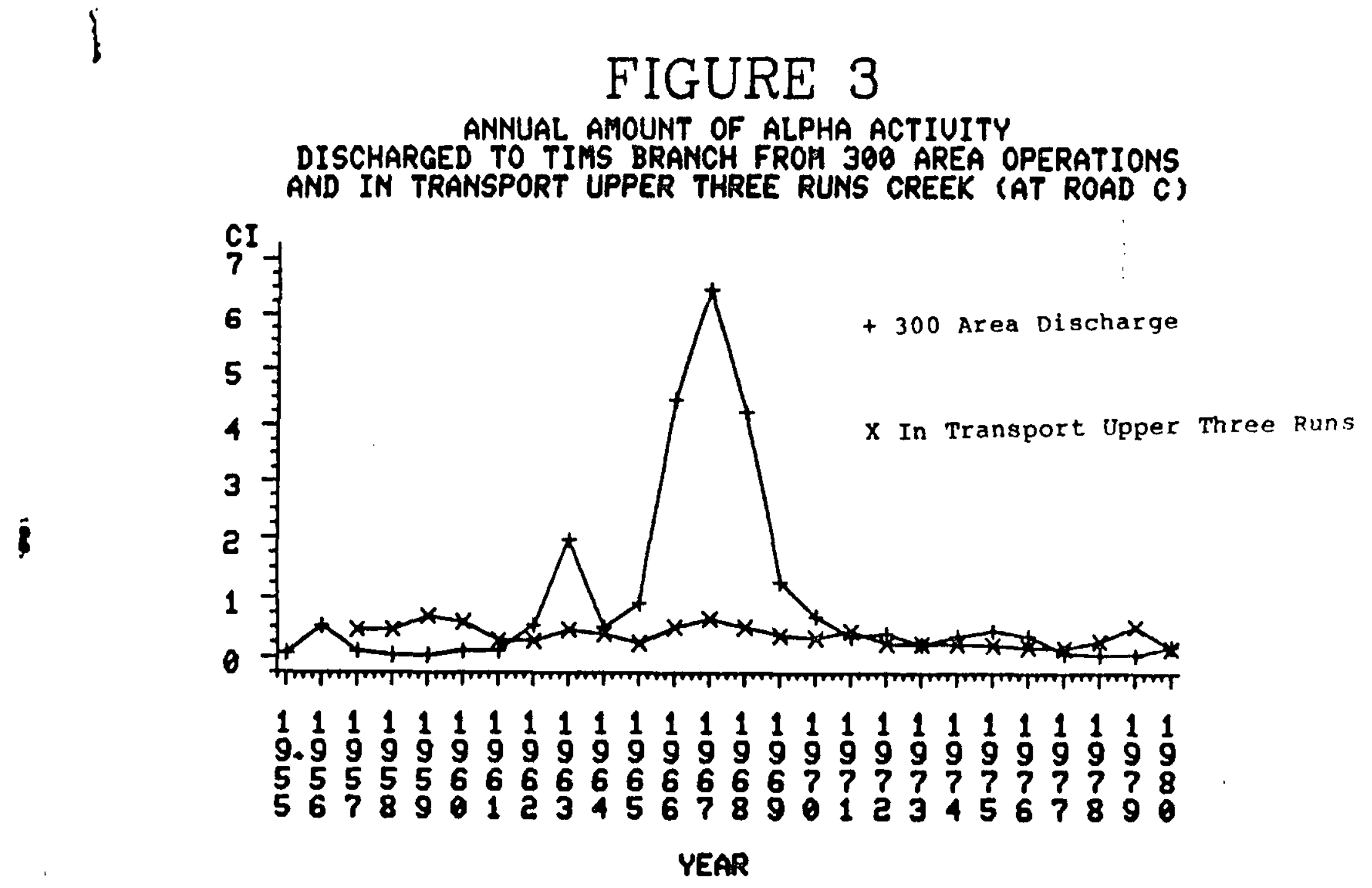




\section{FIGURE 4}

ELEUATION OF TIMS BRANCH SYSTEM

FROM 300 AREA OUTFALL TO UPPER THREE RUNS CREEK

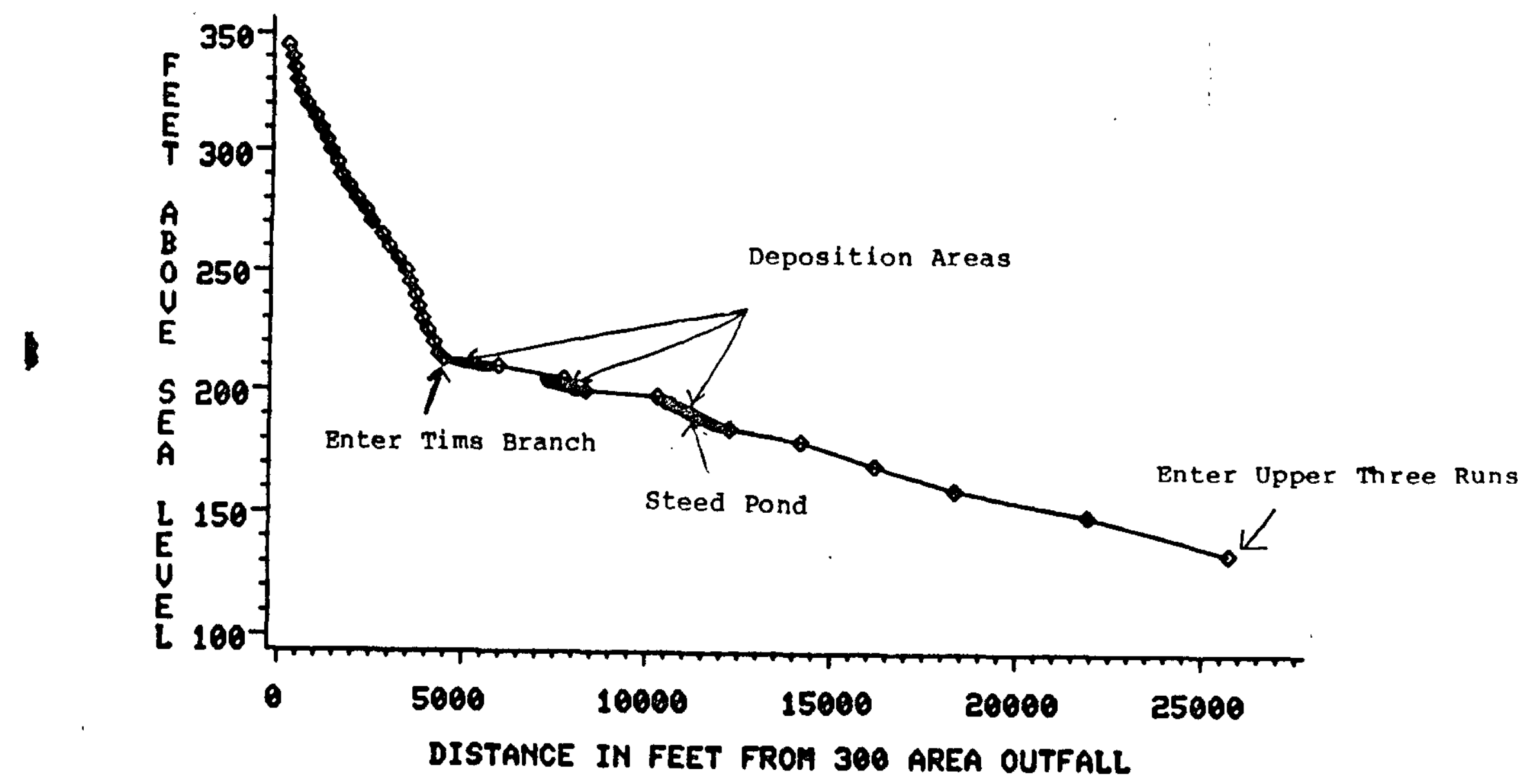




\section{South Carolina Department of Health and Environmental Control}

2000 sint 3

Columbus SC.:901

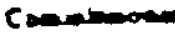

Roten S Jecton. MD

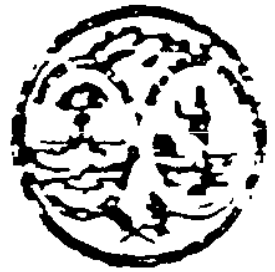

January 31, 1984

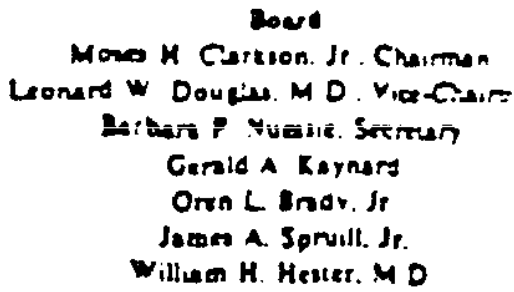

Jemen A. Sorvilt. Jp.

Willinen H. Herter. MO

Mr. Grover A. Smithwick, Director

Office of Environirent

Department of Energy

Savannah River Plant

P.O. Box A

Aiken, S.C. 29801

Re: US DOE/Savannah River Plant

Propósed ï-Area Treatunent plant Aiken County

Dear Mr. Smithwick:

Pursuant to your letter dated November 15, 1983 the proposed effluent imitations for the M-Area process treatment plant are as follows:

Pollutant

Lead(Total)

iiexel (Total)

Copper(Total)

Aluminum (Total)

Iron(Total)

Phosphorous

0 il and Grease

Total Suspended Solids

Uranium(Total)

Zinc(Total)
Instant. Maximum(ma/l)

0.15

1.41

0.5

4.55

1.23

16.7

20

60

0.4

0.70
Monthly Averace(nc/l)

0.13

1.00

0.25

1.86

0.63

6.83

10

23

0.2

0.35

The limitations for aluminum, iron, lead, phosphorous and total susferced solids are based ucon the Federal guidelines requested in your letter dated November 15, 1983. The uranium, nickel, copper and zine limits are base? upon the following calculations: 


\section{Assume:ions:}

1. 7010 stream flow $=0.4$ CFS $=250,500 \mathrm{spd}$

2. Process flow $-144,000 \mathrm{gpd}$

3. llear zero background metal concentrations

4. Outfall A-001 flcm - $172,000 \mathrm{gpd}-$

5. Outfall A-003 flow - 80,000 gpd-

6. Outfall A-01l flow - 105,000 gpd

7. Outfall A-014 flow - 1,100,000 gpd

8. EPA Water Quality Assessment Information

\section{Coocer}

0.1 times a 96-hour $L C_{50}$

96-Hr. LC 50 for bluegills --.66 ma/T CuSO $45 \mathrm{H}_{2} \mathrm{O}$ (from EPA 'Red BOOK')

Molecular weight for $\mathrm{CuSO}_{4}-5 \mathrm{H}_{2} \mathrm{O}=249.5$ grams per mole

$0.1(1.66 \mathrm{mg} / 1) \times \frac{1 \mathrm{gr} / \mathrm{mole} \mathrm{Cu}}{\mathrm{Igr} / \mathrm{mole} \mathrm{CuSO}_{4} \cdot \mathrm{SH}_{2} \mathrm{O}} \times \frac{1 \mathrm{gr} / \mathrm{mole} \mathrm{CuSO} \cdot 5 \mathrm{H} 2 \mathrm{O}}{249.5 \mathrm{gr} \mathrm{CuSO} 4 \cdot 5 \mathrm{H}_{2} \mathrm{O}} \times$

$$
\frac{63.5 \mathrm{grCu}}{1 \mathrm{gr} / \mathrm{mole} \mathrm{Cu}^{3}}=0.0168 \mathrm{mg} / \mathrm{l}
$$

172,000 gpd $(0)+80,000$ gpd $(0)+105,000$ gpd $(0)+1,100,000(0)+$

258,500 gpd $(0)+144,000$ (Cu $=1,859,500$ gpd $(0.168)$

$\{C u\}=0.22 \mathrm{mg} / \mathrm{l}$ allowable instream

$\therefore$ use $0.25 \mathrm{mg} / 1$ monthly average

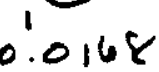

and $0.50 \mathrm{mg} / 1$ instantaneous maximum

Zine

From EPA 'Red 800k' the $96 \mathrm{Hr}$. LC 50 limit for zine is $5.37 \mathrm{mg} / \mathrm{l}$ as $\mathrm{ZnCl} 2$ or $(0.01) \times\left(5.37 \mathrm{mg} / 12 \mathrm{nCl}_{2}\right) \times \frac{(1 \mathrm{~mole} 2 \mathrm{nCl}(\mathrm{2})}{(65.37+70.9 \mathrm{gms})}$

$\times \frac{1 \text { Mole } \mathrm{Zn}}{1 \text { Mole } \mathrm{ZnCl} \mathrm{I}_{2}} \times \frac{65.37 \mathrm{gms}}{1 \text { Mole } \mathrm{Zn}}=0.0253 \mathrm{mg} / \mathrm{l} \mathrm{n}$

Simplifying the mass balance equation yieids

$Z Z n:_{2}=12.31 \times 0.0258$

$\vdots \mathrm{Zn}:=0.33 \mathrm{mg} / \mathrm{l}$ allowable instream

$\therefore$ use 0.35 ro. 1 monthly average and $0.70 \mathrm{ng} / \mathrm{l}$ instantaneous raximum

We rave added zinc to the proposed limitation due to its syneroistic efiec: when discharged with copper.

$\underline{\text { Uranium }}$

From a Tarzwell and Henderson study (1956) the 96-hour $\mathrm{TL}_{m}$ for fathead minnows in soft water was $3.1 \mathrm{mg} / 1$ for uranyl nitrate. $\mathrm{UO}_{2}\left(\mathrm{NO}_{3}\right)_{2} \cdot 6 \mathrm{H}_{2} \mathrm{O}$. Assumie instream allowable limit of 0.01 times $96-$ hour $T L_{m}$ and molecular weight for uranyl nitrate is 502.03 grams per mole. 
Paģe 3

January $3:$, :j::

$$
\begin{aligned}
& =\quad \therefore \sin (0+i j \\
& 0.01 \times(3.1 \mathrm{mg} / 1) \times \frac{1 \text { gr-mole } U}{1 \text { gr-mole Uranyl nitrate }} \times \frac{238.02 \text { or } U}{1 . g r-m o l e ~} \times
\end{aligned}
$$

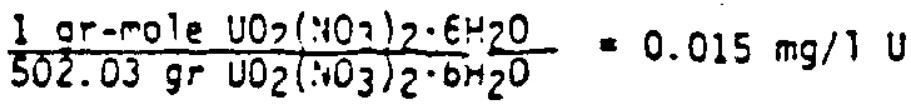

Nickel

From EPA 'Red Book', a stream concentration of $0.1 \mathrm{mg} / 1$ is indicated as not being harmful to aquatic organisms. Using the mass balance equation yields.

$$
\text { (Ni })=12.9 \times 0.1 \mathrm{mg} / \mathrm{l}
$$

$\{\mathrm{NI}\}=1.29 \mathrm{mg} / 1$

However, there is a question of a $0.1 \mathrm{mg} / 1$ nickel instream concentration affecting the reproduction of freshwater crustaceans. Therefore, based upon the Aluminum forming guidelines, limits of $1.00 \mathrm{mg} / 1$ monthly average and 1.41 instantaneous maximum are proposed.

A TTO limit can't be given at this time because we need to know specifially what toxic organics are to be discharged. A $2.13 \mathrm{mg} / \mathrm{l}$ limit for many of the toxic organics would be too high to ma intain stream quality. Also, due to the pollutant load into the system it is felt that the stricter oif and grease guidelines should apply. Therefore, 1 imits of $10 \mathrm{mg} / \mathrm{l}$ monthly average and $20 \mathrm{mg} / \mathrm{l}$ instantaneous maximum were selected.

Of course these limits are based upon the assumed 7010 flow of 0.2 CFS. This best estinate of the 7010 flow is conservative but somewhat nebulous.

The report entitled Tim's Branch Orainace Arez - Stream Flow 3 Analys is Study does nothing to firm up a figure. Our corments concerning this report are as follows:

1. Section 3, Parts A2 \& A3

In this case, 7010 probably should not be estimated on basis of drainage-area ratio but rather on a correlation based on near-sim:1taneous current-meter measurements of site 4 and the USGS gaçinc station. Accuracy of the measurement of site 4 will be discussed letier.

In Part $C$ conventional means could have been used. See coment :10. 3

2. Section 5

Heirs are accurate and reliable devices for measuring flows when they are installed and used exactly as they were calibrated in laboratories. If field conditions depart significantly from lab conditions, the calibration equations becorre invalid. The report does not describe the installations completely enough for us to make an appraisal of the probable accuracy. 


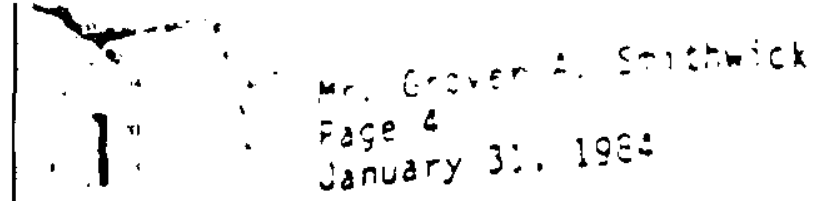

The ratio of weir height to channel depth is critical because it affects velocity of approach to the weir as well as the pattern of flowlines. If the bottom of the weirs were installed too low or if sediment was dedosited in the weir pool during the several days between construction and the study, weir equations would be altered significantly.

The position where the head on the weir ts measured and the method used to measure it are very important. In the second paragraph on page 5-1. measuring depth with a ruler is menttoned. If the depth of water is measured in the notch of the triangular weir with a ruler then a large error in flow computation would occur. Current-meter measurements should have been made to verify weir ratings during the study.

\section{Section 6}

Even though the USGS gaging station was discontinued, nearsimultaneous current-meter measurements should have been made to establish a correlation.

4. Mr. John Stallings, Division of Water Quality Assessment and Enforcement, at 758-5496, is available for further detailed discussion of the report.

Therefore, until additional information is submitted to OHEC the 7010 flow for Tim's Branch should be $0.4 \mathrm{cfs}$. If you have any questions concerning this matter please call me at 758-5493.

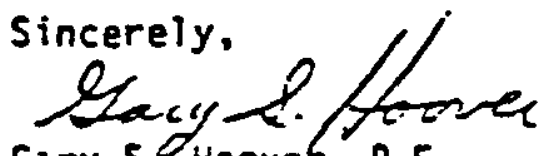

Gary S? Hoovef. P.E.

Industrial \& Agricultural Wastewater Jivision Bureau of Water Pollution Control

$G S H / j F$

cs: Kin Hill. Lower Savannah District 
DPST-84-847

\title{
URANIUM STUDIES IN THE TIMS BRANCH AND STEED POND SYSTEM (U)
}

\author{
by \\ D. W. Hayes
}

Westinghouse Savannah River Company

Savannah River Site

Aiken, South Carolina 29808

Technical deliverable being deposited with OSTI.

The information contained in this report was prepared in connection with work done under Contract No. DE-AC09-76SR00001 with the U.S. Department of Energy. By acceptance of this report, the publisher and/or recipient acknowledges the U.S. Government's right to retain a nonexclusive, royalty-free license in and to any copyright covering this report, along with the right to reproduce and to authorize others to reproduce all or part of the copyrighted report. 
This document has been used as a historical reference in the "Radionuclides in the SRS Environment" series. It does not necessarily represent current conditions at SRS. 
TECHNICAL DIVISION

SAVANNAH RIVER LABORATORY
DPST $-84-847$

CC: W. M. Olliff, SRP

J. D. Clayton

L. P. Fernandez

H. C. Drannon

C. F. Muska

M. D. S. Turcotte

J. S. Roberts

M. B. Hughes

M. W. Lewis

C. A. Palmiotto

D. I. Ross

C. C. Zeiglex

T. V. Crawford, SRL

A. L. Boni

J. C. Corey

J. B. Pickett

November 1,1984

\section{MEMORANDLM}

TO: R. W. BENJAMIN

FROM: D. W. HAYES NUW

CRANIUM STUDIBS IN TBE TIMS BRANCB AND STEEA POND SYSTEM SUMMARY

During the weekend of September $2-3,1984$, a part of the wooden spillway for steed pond gave way and the pond slowly drained. Consideration is being given to leaving steed Pond dry. steed Pond has accumulated some of the uranium discharged from 300 Area operations and past surveys have shown that the uranium concentration in the sediments ranges between 20 and $531 \mathrm{pCi} / \mathrm{gm}$. 
The recently completed aerial survey of the exposed area of Steed Pond showed that the uranium was widely spread in the sediments of steed Pond. Until ground cover is established over the exposed pond sediments, they will be subject to erosion. As much as 90 tons of sediment could be eroded from the exposed sediments in steed Pond the first year, but the erosion could be reduced to 5 - 15 tons by establishing a ground cover such as rye grass. Only about 408 of the eroded sediment would be delivered to Upper Three Runs Creek, because most of the eroded sediment is deposited before it reaches Upper Three Runs Creek. Less than 20 $\mathrm{mCi}$ of uraniun would be transported downstream the first year from erosion of Steed Pond sediments, and this could be reduced to 2-5 mci/year if ground cover is established.

The preliminary results from these calculations were reported at a Steed Pond review on September $20,1984$.

\section{INTRODOCTION}

The 300 area operations have discharged about 24 curies of alpha activity (uranium) to Tims Branch since 1954. Tims Branch flows through steed Pond, over a wooden spillway and then downstream until it empties into Upper Three Runs Creek at Road $C$. Based on monitoring of Upper Three Runs Creek, nearly all of the alpha activity discharged from 300 Area operations was deposited in the Tims Branch and Steed Pond stream system. During the 
weekend of September 2-3, 1984, a part of the wooden spillway gave way and the pond slowly drained. The sediments in steed Pond containing uranium from 300 Area releases are now exposed and subject to erosion. Earlier analyses of a few surface sediment samples from the pond indicate that the uranium concentration ranges from 20 to $531 \mathrm{pci} / \mathrm{gm}$ in the sediments. Since some consideration is being given to leaving the spillway open and the pond drained, an analysis of the amount of uranium that might be transported from the exposed sediment in steed Pond and the conditions that resulted in uranium originally being deposited in the Tims Branch and steed Pond stream system was studied.

\section{DISCOSSION}

\section{Alpha Activity Source}

About 24 curies of alpha activity have been discharged to the Tims Branch system from 300 Area fuel target fabrication operations (Figure 1). From the early 1950's until the mid 1960's, most of the alpha activity discharged was natural uranium $(0.728$ U-235) along with a small amount of enriched uranium $(0.898$ U-235). The alpha activity discharged since the mid 1960's is due to depleted uranium $(0.28 \mathrm{U}-235)$. A small amount of alpha activity from Th-232 may have been released in 1967 and 1968 . 
The source of this discharged alpha activity is waste from cleaning and recovery operations in the 300 Area. In the process of making the fuel or target elements, uranium slugs are cleaned in step operations with perchloroethylene, nitric and phosphoric acids. The cleaning removes alpha activity from the surfaces of the slugs used to fabricate fuel or target elements. The used chemicals from this cleaning operation are treated and the waste water containing traces of the residual alpha activity is discharged. Some alpha activity in the waste water was also released from the process used to recover uranium from fuel and target elements that failed specifications or tests. The waste water from all these sources entered a Tims Branch tributary near the 700 Area waste water treatment plant on Road D (Figure 2). An accounting of the gross alpha activity released at the discharge point and the alpha activity in transport in upper Three Runs Creek below the confluence with Tims Branch (at Road C), shows that most of the alpha activity discharged is still in the Tims Branch system. About 8 curies of the total alpha activity was measured in transport in Upper Three Runs as compared to 24 curies of alpha activity discharged to Tims Branch from 300 Area operations. Even during years of peak alpha activity discharges from the 300 Area, the alpha activity in transport in Upper Three Runs Creek remained nearly constant (compare Figure 3). These results show that most of the alpha activity is still in the Tims 
Branch system. The actual 300 area alpha activity contributions to Upper Three Runs creek cannot be accurately evaluated because the concentrations are very low due to dilution and near background alpha activity levels. However, source of uranium in transport in Upper Three Runs Creek could be determined by measuring the uranium isotopic ratio.

\section{Alpha Activity Deposition}

The recently completed aerial radiological survey of the Tims Branch system by EG\&G showsthat the locations of the major depositional areas for uranium are near the entrance of 300 Area effluents into Tims Branch and steed Pond (Figure 2). The area if ${ }^{238} \mathrm{Wis}$ between Steed $\$$ Pond and Upper Three Runs did not show the presence ot persut, of U-238. The U-238 was identified by the presence of Pa-234, a hou to wh nati it? natul chain daughter product of $\mathrm{U}-238$.

The conditions for deposition of uranium in Tims Branch is are influenced by the stream morphology. The discharges from the 300 Area enter a tributary of Tims Branch adjacent to Road $D$ and the railroad track (Figure 2) and flow down a rather steep slope which intersects with Tims Branch (Figure 4). Over the years considerable erosion has occurred in this tributary as it adusted to accommodate the increased flow from the 300 area and to increased peak storm flow due to large buildings and paved areas in the headwaters of the tributary. The erosion in the tributary prevented the deposition of appreciable quantities of uranium in the tributary. At the bottom of this slope most of the eroded 
sediment was deposited in the floodplain of Tims Branch near the intersection. The abrupt change in slope at this point 138 to 0.48 ) reduced the capacity of the water to carry the sediment so this was wheremost of the sediment was deposited.

The water then flows a low slope (0.48) distance of about 5800 feet until it enters steed Pond. Steed Pond acts as a settling basin and has a residence time for Tims Branch water flow of about 3 days ( 11 acres * 43560 feet $2 /$ acre * 4 feet/5 cfs). This residence time is sufficient for the settling of flow-borne alpha activity as evidenced by the presence of U-238 in the sediments of steed Pond. An accumulation of sediment of about 3 feet in the vicinity of the steed Pond spillway shows the result of sediment deposition.

Steed Pond originally had an area of about 14 acres, and an area of about 11 acres when the spillway gave way in september 1984. In the early 1960's the spillway was removed and the pond drained. Based on aerial photos, the pond still had a few acres of water in 1966 indicating that the spillway was only partially removed. In the early 1970's the spillway was repaired and the pond returned to a surface area of about 11 acres, about 3 acres less than the original 14 acres. Because the spillway has never been completely removed, the pond has always functioned as a sediment trap with varying efficiencies based on the amount of water in the pond. 
After the water leaves Steed Pond, it travels about 13,700 feet at about the same slope $(0.48)$ until it enters Upper Three Runs. Since the slope gradient below Steed Pond is the same as above the pond, it is an extension of the depositional conditions that exist in the area above steed pond.

The chemistry of the waste water effluents from the 300 Area and the presence of eroded sediments have probably enhanced the deposition of uranium. The waste water effluent contained phosphates, and phosphates form insoluble compounds with uranium which could be deposited. The eroded sediments provide sorption surfaces for the discharged uranium ( $\mathrm{kd}$ about 50 ) and in addition phosphates could sorb to sediment surfaces and form an enhanced sorbant for uranium from solution to the sediments.

\section{Toxicity}

The chemical toxicity of uranium may be more important than the radiotoxicity. The ICRP in establishing radiologic concentration guides, recognized that the chemical toxicity of the longer lived nuclides $(U-235$ and $U-238)$ was the limiting criterion (ICRP Publication 2, 1960). In the National Interim Primary Drinking Water standards no maximum contaminant levels have been established for uranium. The DOE alpha activity guideline is 30 $\mathrm{pCi} / \mathrm{L}$. 
Proposed effluent limitations for the 300 Area operations were made by DHEC. In a letter to DOE (January 31,1984 ) effluent limitations for uranium of $0.2 \mathrm{mg} / \mathrm{L}$ monthly average and $0.4 \mathrm{mg} / \mathrm{L}$ instantaneous maximum were proposed for the M-Area treatment plant discharges (see Appendix A). These proposed effluent guidelines were estimated from a toxicity study done on fathead minnows and water flow balances in the area that would result in a stream concentration of $0.015 \mathrm{mg} / \mathrm{L}$.

No stream water concentration guidelines exist for the movement of established floodplain uranium downstream.

\section{Transport of 0 Prom steedó Pond}

The exposed sediments of steeds Pond are subject to the processes of erosion and transport down Tims Branch and into Upper Three Runs creek. An estimate of the amount of sediment that could be eroded from the exposed sediments was obtained using the Universal Soil Loss Equation (USLE, Appendix).

The USLE equation includes the factors that are important in estimating the amount of erosion (soil movement to the base of a slope), and the US Department of Agriculture has developed sets of specific and regional factors for use in the USLE equation. Approximately 90 tons of sediment may be eroded in steed Pond (10 acres). Not all of this sediment will reach Upper Three Runs Creek. During the erosion stream delivery process, most of this 
soil will be deposited near the bottom of the slope and a small amount will be lost in stream transport. A correction for this reduced sediment yield downstream is made by using factors called delivery ratios. Delivery ratios are about 0.4 for small watershed streams in the sandhills of South Carolina. Therefore, about 36 tons/year ( 90 tons $* 0.4$ ) of sediment may be delivered to Upper Three Runs Creek the first year.

The amount of alpha activity that may be transported to Upper Three Runs can be estimated from the erosion yield and uranium concentration in Steed Pond sediments. A survey of Steedpipond sediments was made in 1966, from these 6 samples most of the uranium was found in the surface sediments and the concentration ranged from 20 to $531 \mathrm{pCi} / \mathrm{gm}$. Using a concentration of $531 \mathrm{pCi} / \mathrm{gm}$ a maximum of about $17 \mathrm{mCi}$ per year would be transported to upper Three Runs. This $17 \mathrm{mCi}$ would convert to an average annual uranium concentration in Tims Branch water of about $3.8 \mathrm{pCi} / \mathrm{L}$ at a flow of $5 \mathrm{cfs}$. The alpha activity contribution from this erosion would result in an increase of alpha activity in Upper Three Runs Creek of about $0.07 \mathrm{pCi} / \mathrm{L}$, which is about 108 of the alpha activity concentration present in Upper Three Runs Creek 10.8 $\mathrm{p}(\mathrm{i} / \mathrm{L})$.

The alpha activity concentration can be translated to concentration of uranium by using the specific activity for natural uranium of $3000 \mathrm{~kg} / \mathrm{Ci}(333 \mathrm{pCi} / \mathrm{mg})$. Therefore, the 
average annual uranium concentration in Tims Branch water below Steed Pond would be about $0.011 \mathrm{mg} / \mathrm{L}$.

The amount of erosion of the exposed sediments in Steed pond can be greatly reduced if ground cover is established. In the fertile exposed sediments of Steed Pond, revegetation will be especially rapid next spring. Even now some grass can be seen growing in the exposed sediments (October 25, 1984). If ground cover (rye grass) is established now and there is natural revegetation next spring, the overall reduction in erosion yield during the first year would be a factor of 10 to 15. This reduction occurs because the cropping management factor is reduced from 0.5 to $0.03-0.05$. The estimates of sediment transport, alpha activity, and uranium concentration would be reduced by the same factors. The alpha activity concentration in Tims Branch below steed pond would be reduced to $0.38 \mathrm{pCi} / \mathrm{L}$.

The calculations made include only hill-slope erosion processes. Additional sediment may be transported to Upper Three Runs Creek, if the entire spillway is removed. Over the years considerable sediment has accumulated in the pond and if the spillway were entirely removed, the stream would cut through these accumulated sediments. The sediments would move downstream and into Upper Three Runs Creek. No estimate has been made on the quantity of sediment that might be moved by this process, because no data are available on the accumulation of sediment in the pond. 
Some aerial stereo photo pairs are currently being processed to estimate the amount of sediment that might have been accumulated in steed $\$$ Pond.

\section{PROGRAM}

A program has been started to assess the yield of sediment and uranium from the erosion of the exposed sediments in steed Pond and the environmental parameters that most strongly affect the erosion and transport of these pollutants. The program elements are:

1. The amount of sediment and uranium from the erosion of sediments in steed Pond will be determined from the analysis of water samples taken by automatic water samplers located below the steed Pond Dam.

2. The amount of the sediment and uranium that reach upper Three Runs Creek will be determined from water samples taken at the mouth of Tims Branch.

3. A recording rain gauge has been installed at steed $\$$ Pond to determine the effect of the intensity, amount, and duration of rainfall on the sediment yield from erosion of sediments in Steed Pond.

4. To evaluate steed Pond as a settling basin during heavy rains, a water level recorder will be installed on the pond side of the dam. 
5. The measurements from items 1 and 2 above will be interpreted in view of the results from 3 and 4. 


\section{APPENDIX}

$A=\operatorname{RKLSCP}$

$A=$ Soil loss rate in tons/acre-year.

$R=$ The rainfall intensity factor, which relates both the amount of rain and its intensity and is about 260 for this area.

$K=$ The soil erodability index is dependent upon the type of soil and the logical candidate soil would be of the Bayboro type, a silty clay loam soil. The soil erodability index for this soil is 0.17 .

LS $=$ The hillslope length and hillslope gradient factors are combined. A slope of 38 was estimated by taking the approximate distance from the edge of the pond to the centerline ( 300 feet) and dividing it by the change in elevation from the edge to the center (about 8 feet). A factor of 0.4 was obtained from slope-slope length tables (Table 1)

$P=$ The erosion control factor includes practices such as contouring to reduce erosion. Because no erosion control methods are to be employed for Steed $\$$ Pond, this factor is set at 1 (coefficients are 1 or less).

$c=$ The cropping management factor includes the effect of vegetative cover. Without any vegetative cover over the exposed sediments, this factor is about 0.5 . 


\section{FIGURE 1}

ANMUAL AMOUNT OF ALPHA ACTIUITY DISCHARGED

FROM 300 AREA OPERATIONS

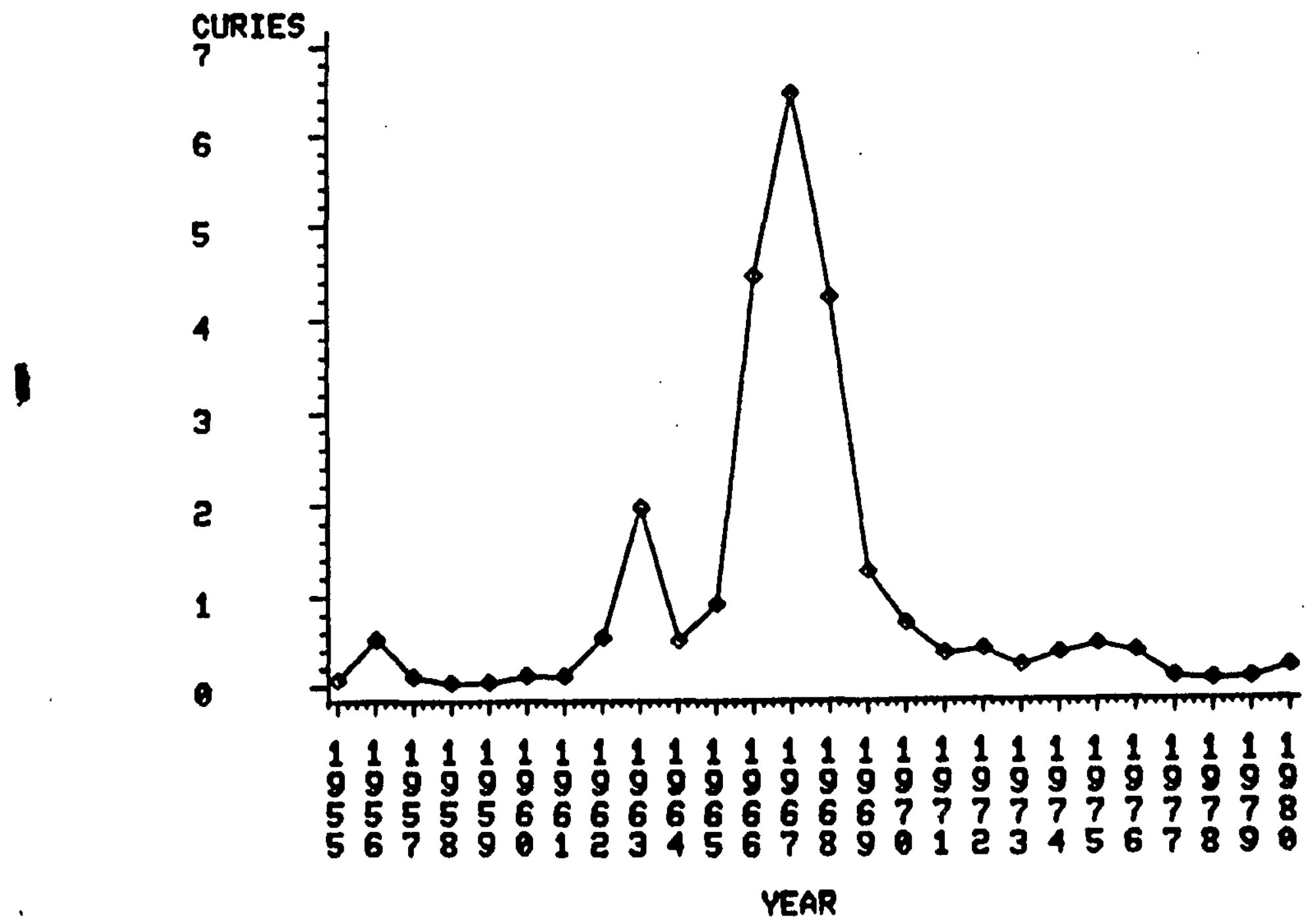


Pigure 2. Map of steed Pond and Tims Branch system

300 Area

Discharge
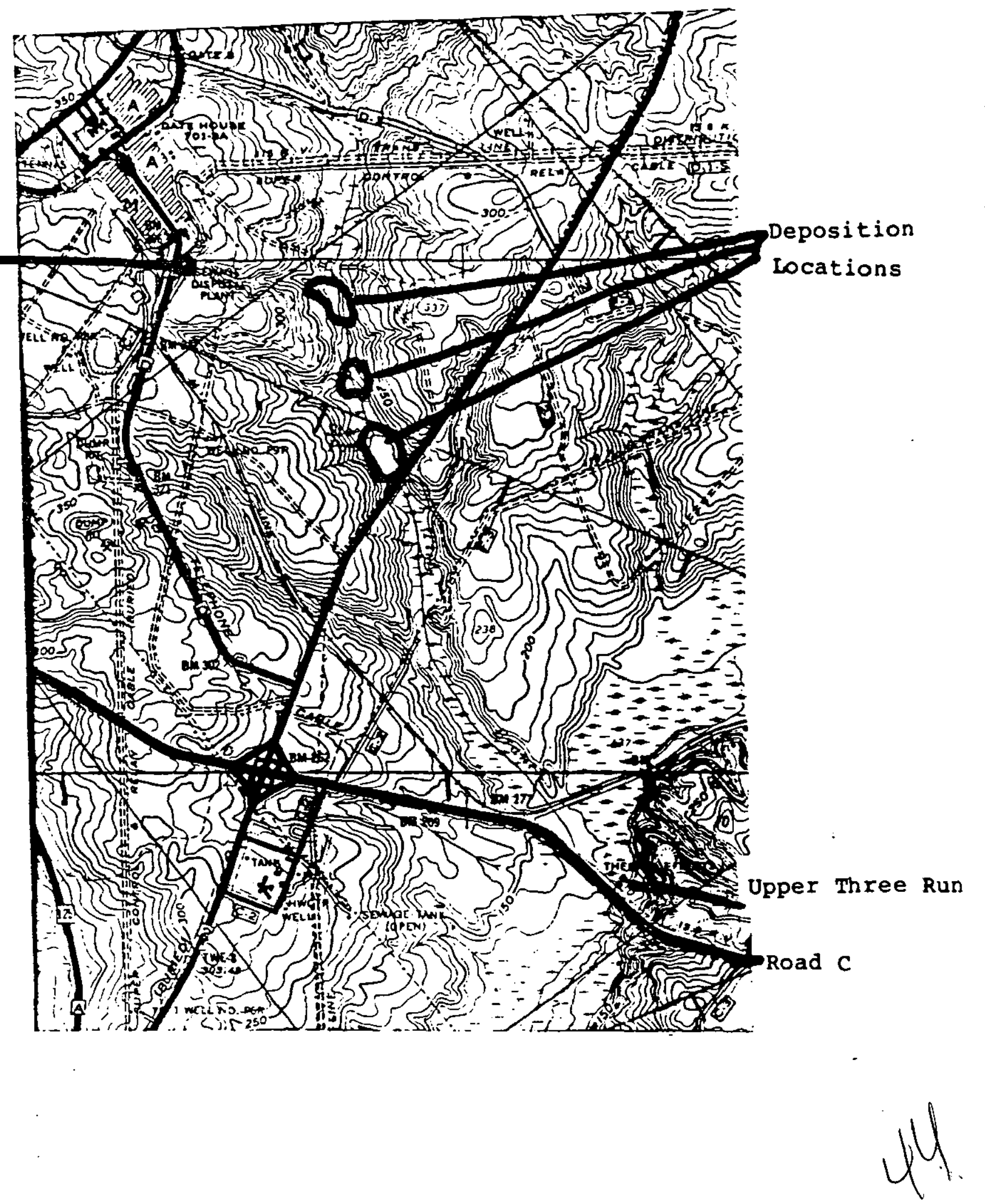


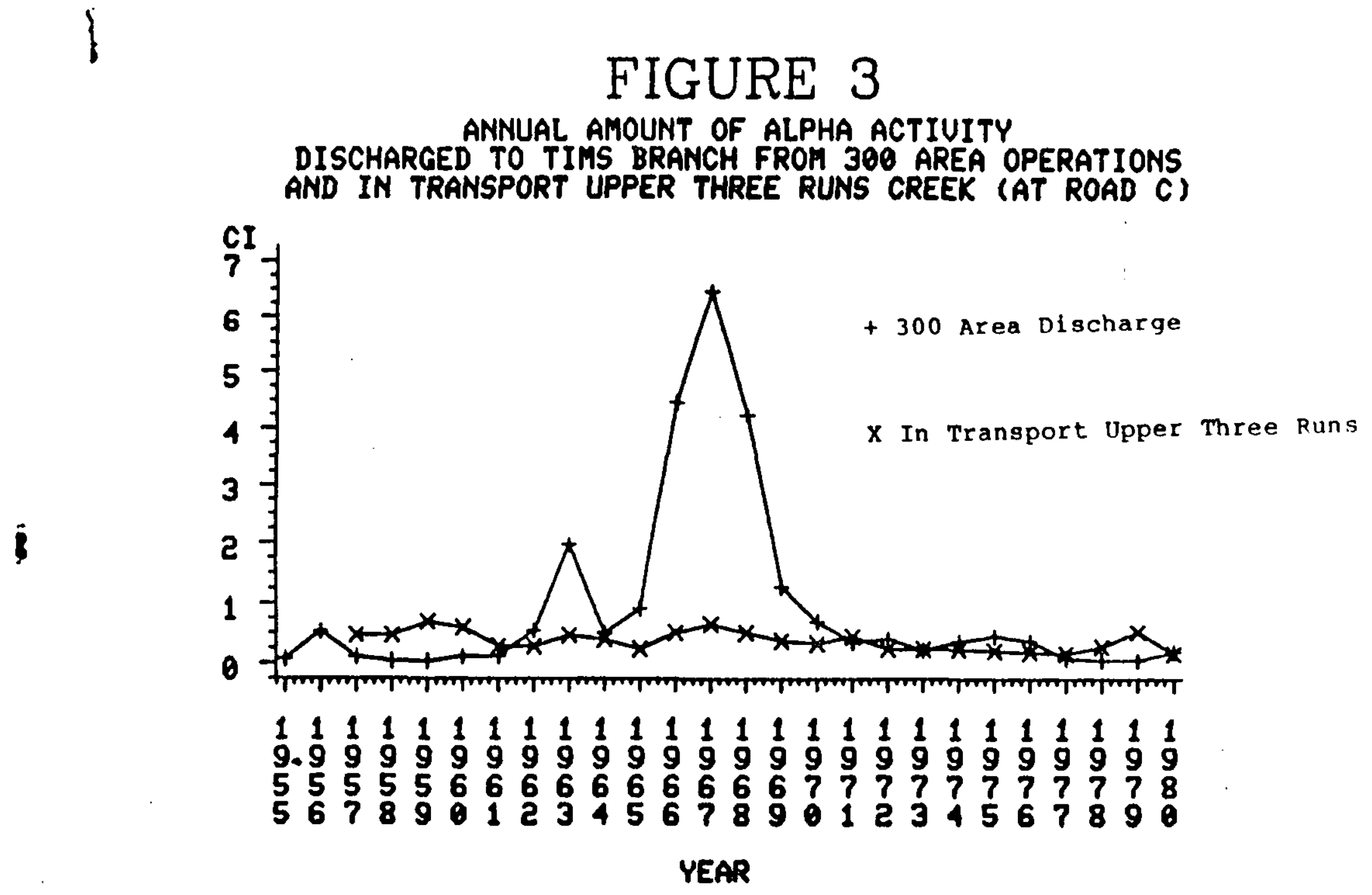




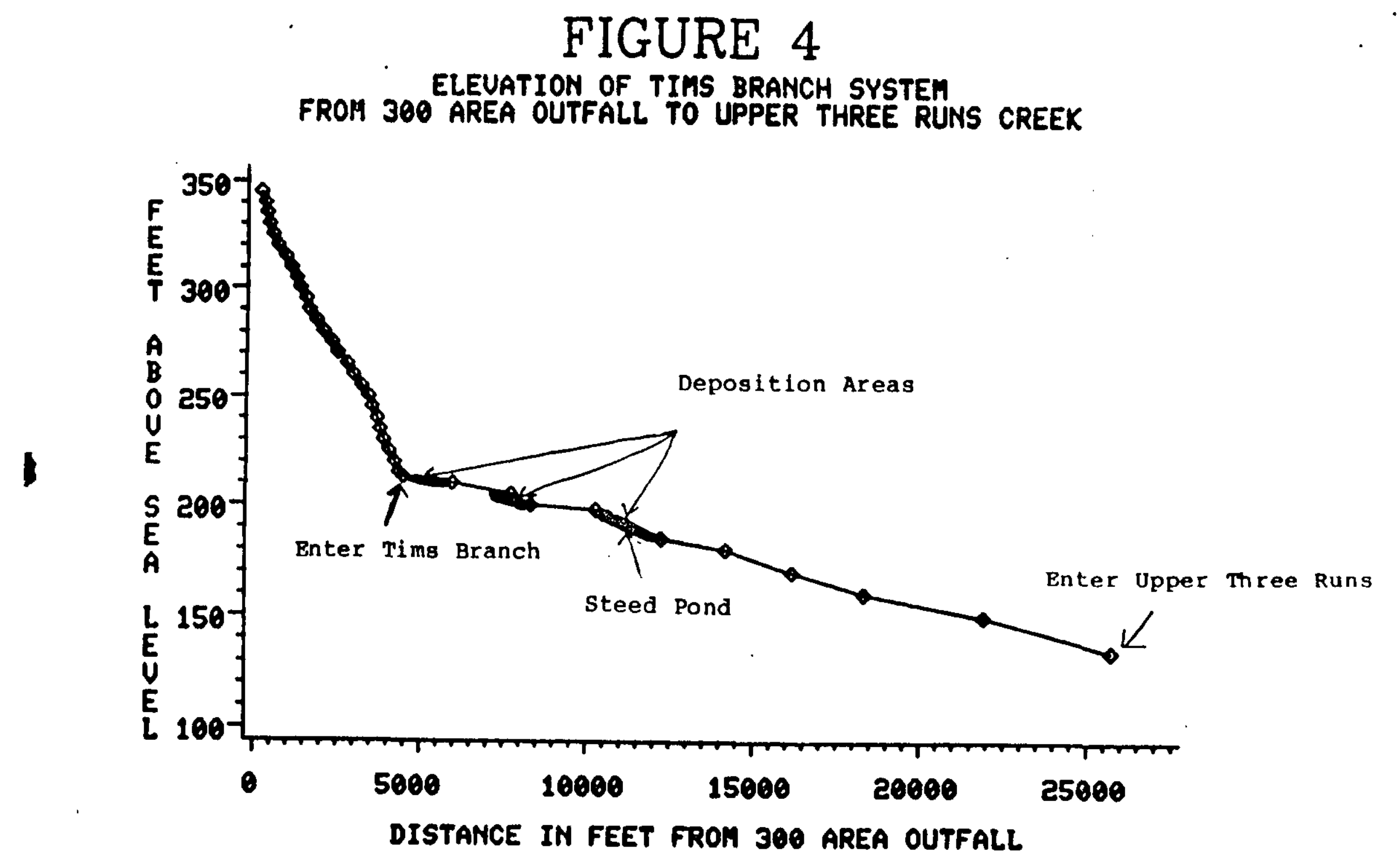




\section{South Carolina Department of Health and Environmental Control}

200 bin sing Columbu. 5 C :501

\section{Comantom}

Rours Jecuon. M. D

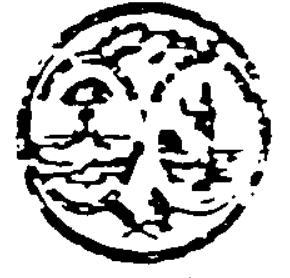

January $31^{\circ}, 1984$
Coest

Mong H Cerwon. Je. Chairman Lonard Dougin. M D Victerert Riban P Yuabic. Secrun? Cernie a xarners Oren L Bnav, Jr Jom a. Spruall. Je. willean H. Hester. MD

Mr. Grover A. Smithwick, Director

Office of Environment

Departnent of Energy

Savannah River Plant

P.0. Box A

Aiken, S.C. 29801

Re: US DOE/Savannah River Plant

Proposed M-Area Treatment Plant Aiken County

Dear Mr. Smithwick:

Pursuant to your letter dated November 15. 1983 the proposed effluent limitations for the M-Area process treatient plant are as follows:

Pollutant

Lead(Total)

Nickel(Total)

Copper(Total)

Aluminum(Total)

Iron(Total)

Phosphorous

0 il and Grease

Total Suspended Solids

Uranium(Total)

Zinc(Total)
Instant. Maximumi(ma/1)

0.15

1.41

0.5

4.55

1.23

16.7

20

60

0.4

0.70
Monthly Averace (me/1)

0.13

1.00

0.25

1.86

0.63

6.83

10

23

0.2

The limitations for aluminum, iron, lead, phosphorous and total susperces solids are based ucon the Federal guidelines requested in your letter oa:es November 15, 1983. The uranium, nickel, copper and zine limits are basec upon the following calculations: 


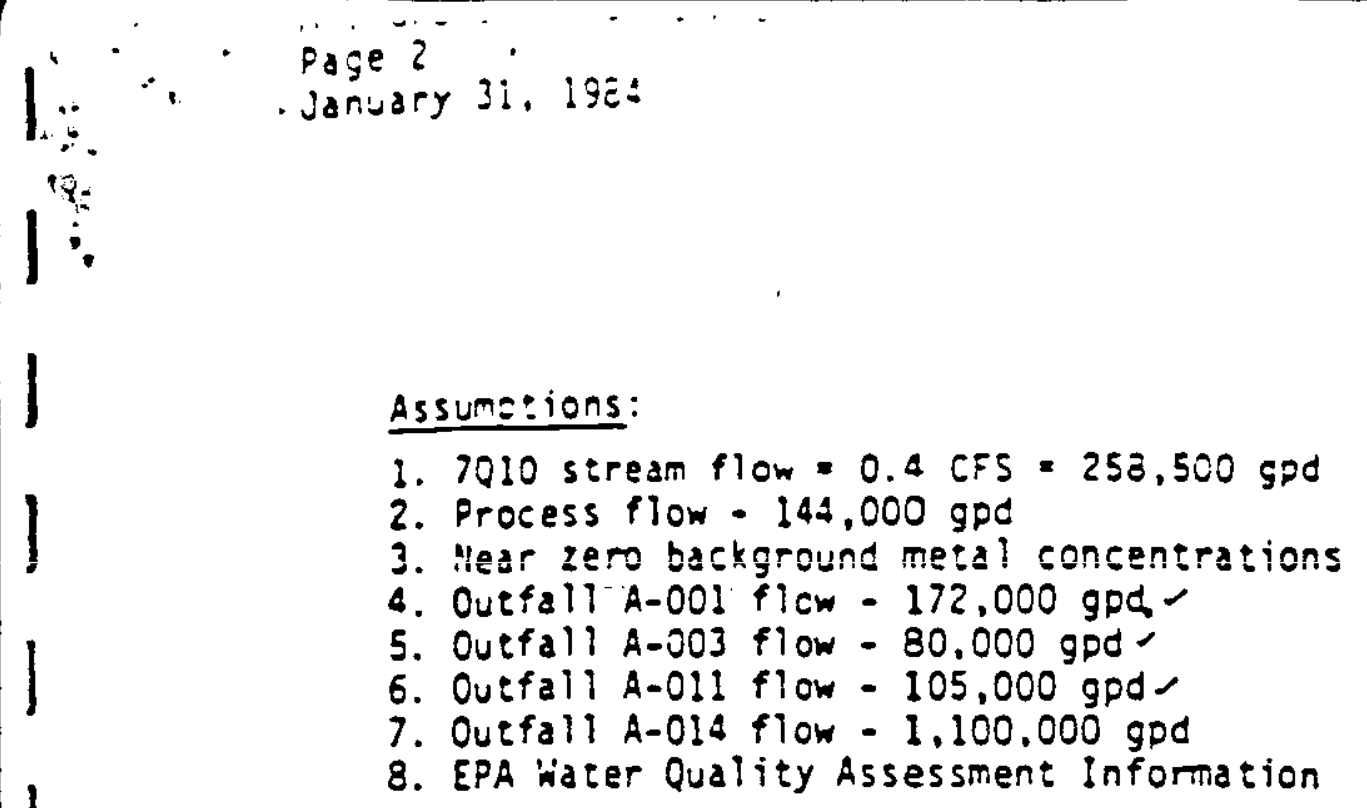

Assums:ions:

2. Process flow - 144,000 gpd

3. Hear zero background metal concentrations

7. Outfall A-014 flow - 1.100.000 gpd

8. EPA water Quality Assessment Infomation

\section{Copcer}

0.1 times a 96-hour $L C_{50}$

96-Hr. LC 50 for bluegills --.65 mo/l CuSO $4 \cdot 5 \mathrm{H}_{2} \mathrm{O}$ (from EPA 'Red BOOK') Molecular weight for $\mathrm{CuSO}_{4}{ }^{-5 \mathrm{H}_{2} \mathrm{O}}=249.5$ grams per mole

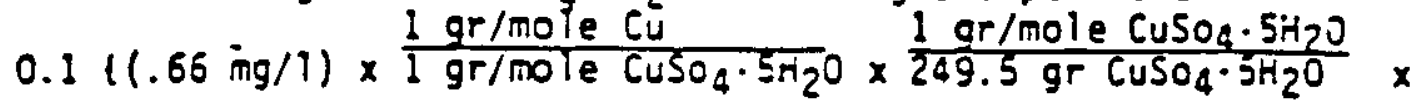

$$
\frac{63.5 \mathrm{or} \mathrm{Cu}}{1 \mathrm{gr} / \mathrm{mole} \mathrm{Cu}^{3}}=0.0168 \mathrm{mg} / 1
$$

172,000 gpd $(0)+80,000$ gpd $(0)+105,000$ gpd $(0)+1,100,000(0) \div$

258,500 gpd $(0)+144,000(\mathrm{Cu})=1,859,500$ gpd $(0.168)$

$\{\mathrm{Cu}\}=0.22 \mathrm{mg} / 1$ allowable instresm

$\therefore$ use $0.25 \mathrm{mg} / \mathrm{l}$ monthly average

and $0.50 \mathrm{mg} / 1$ instantaneous maximum

Zine

From EP.4 'Red Book' the 95Hr. LC50 limit for zine is $5.37 \mathrm{mg} / \mathrm{l}$ as $\mathrm{ZnCl} 2$ or $(0.01) \times(5.37 \mathrm{mg} / 12 \mathrm{nCl} 2) \times \frac{(1 \text { mole } 2 \mathrm{nCl} / 2)}{(65.37+70.9 \mathrm{gms})}$

$$
\times \frac{1 \text { Mole } \mathrm{Zn}}{\text { Mole ZnCT? }} \times \frac{65.37 \text { an.s }}{1 \text { Mole } 2 \mathrm{n}}=0.0253 \mathrm{mg} / 1 \mathrm{Zn}
$$

Simplifying the mass balance equation yieids

I $n:=12.91 \times 0.9258$

$\vdots$ In: $=0.33$ no/l allowable instream

$\therefore$ use 0.35 ro.'l monthly average and $0.70 \mathrm{me} / 1$ instantaneous raximum

We have added $z$ ine to the proposed limitation due to its synergistic e?ioc: when discharged with copper.

\section{Uranium}

From a Tarzwell and Henderson study (1956) the 96-hour TLm for fathead minnows in soft water was $3.1 \mathrm{mg} / 1$ for uranyl nitrate. $\mathrm{UO}_{2}\left(\mathrm{NO}_{3}\right)_{2} \cdot 6 \mathrm{H}_{2} \mathrm{O}$.

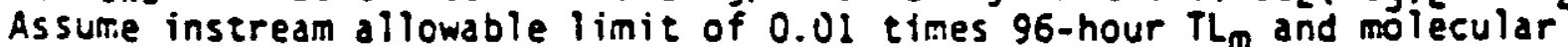
weight for uranyl nitrate is 502.03 grams per mole.

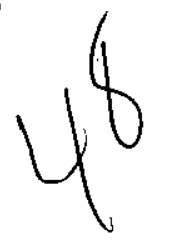




$$
\begin{aligned}
& \text { Q. . Pşe } \\
& \text { January } 3: \text {, :3:: } \\
& -y \quad i \operatorname{sit} 6 x \\
& - \\
& 0.01 \times(3.1 \mathrm{mg} / 1) \times \frac{1 \text { gr-mole } U}{1 \text { gr-mole Uranyl nitrate }} \times \frac{238.02 \text { or } U}{1 . g r-m o l e ~} \times
\end{aligned}
$$

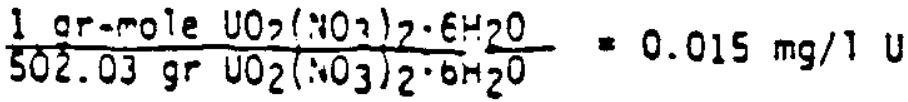

$$
\begin{aligned}
& \text { Using the mass balance yields } \\
& \text { (U) }=12.91 \times 0.015 \mathrm{mg} / 1=0.19 \mathrm{mg} / 1 \\
& \therefore \text { use } 0.20 \mathrm{mg} / 1 \text { monthly average } \\
& \text { and } 0.50 \mathrm{mg} / \mathrm{l} \text { instantaneous maximum }
\end{aligned}
$$

Nickel

From EPA 'Red Book', a stream concentration of $0.1 \mathrm{mg} / \mathrm{l}$ is indicated as not being harmful to aquatic organisms. Using the mass balance equation yields.

$$
\{\mathrm{Ni}\}=12.9 \times 0.1 \mathrm{mg} / 1
$$

$\{\mathrm{Nf}\}=1.29 \mathrm{mg} / 1$

However, there is a question of a $0.1 \mathrm{mg} / 1$ nickel instream concentration affecting the reproduction of freshwater crustaceans. Therefore, based upon the Aluminum forming guidelines, limits of $1.00 \mathrm{mg} / 1$ monthly average and 1.41 instantaneous maximum are proposed.

A TTO limit can't be given at this time because we need to know specifially what toxic organics are to be discharged. A $2.13 \mathrm{mg} / 1$ limit for many of the toxic organics would be too high to ma inta in stream quality. Also, due to the pollutant load into the system it is felt that the stricter oil and grease guidelines should apply. Therefore, 1 imits of $10 \mathrm{mg} / \mathrm{l}$ monthly average and $20 \mathrm{mg} / 1$ instantaneous maximum were selected.

Of course these limits are based upon the assumed 7010 flow of 0.2 CFS. This best estimate of the 7010 flow is conservative but somewhat nebulous.

The resort entitled Tim's Branch Drainace Area - Stream Flow 3 Analysis Study does nothing to firm up a figure. Our corsents concerning this rezort are as follows:

1. Section 3, Parts A2 \& A3

In this case, 7010 probably should not be estimated on basis ci drainage-area ratio but rather on a correlation based on near-sim:i taneous current-meter measurements of Site 4 and the USGS gacinc station. Accuracy of the measurement of Site 4 will be discussed letter.

In Part $C$ conventional means could have been used. See coment :10. 3

2. Section 5

Weirs are accurate and reliable devices for measuring flows when they are installed and used exactly as they were calibrated in laboratories. If field conditions depart significantiy from lab conditions, the calibration equations become invalid. The report does not describe the installations completely enough for us to make an appraisal of the probable accuracy. 


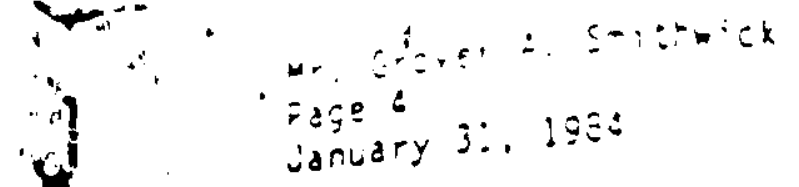

The ratio of weir height to channel deoth is critical because it affects velocity of approach to the weir as well as the pattern of flowlines. If the botton of the weirs were installed too low or if sediment was deposited in the weir pool during the several days between construction and the study. weir equations would be altered significantly.

The position where the head on the weir is measured and the method used to measure it are very important. In the second paragraph on page $5-1$. medsuring depth with a ruler is mentioned. If the depth of water is measured in the notch of the triangular weir with a ruler then a large error in flow computation would occur. Current-meter measurements should have been made to verify weir ratings during the study.

3. Section 6

Even though the USGS gaging station was discontinued, nearsimultaneous current-meter measurements should have been made to establish a correlation.

4. Mr. John Stallings, Oivision of Hater Qual ity Assessment and Enforcement, at 758-5496, is available for further detailed discussion of the report.

Therefore, until additional information is submitted to OHEC the 7010 flow for Tim's Branch should be $0.4 \mathrm{cfs}$. If you have any questions concerning this matter please call me at 758-5493.

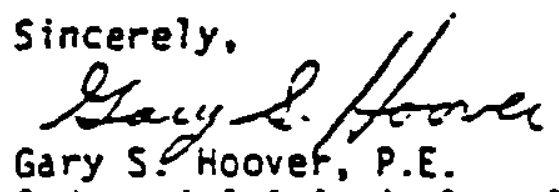

Industrial \& Agricultural Wastewater Jivision Bureau of Water Polliution Control

GSH/jf

c5: Kin Hill, Lower Savannah District 